\title{
Antibiotic resistance in probiotic bacteria
}

\section{Miguel Gueimonde, Borja Sánchez, Clara G. de los Reyes-Gavilán and Abelardo Margolles*}

Instituto de Productos Lácteos de Asturias, Consejo Superior de Investigaciones Científicas, Villaviciosa, Spain

\section{Edited by:}

Henk Aarts, National Institute for Public Health and the Environment, Netherlands

\section{Reviewed by:}

Atte Von Wright, University of Eastern Finland, Finland

Dmitri Debabov, NovaBay

Pharmaceuticals, USA

*Correspondence:

Abelardo Margolles, Instituto de Productos Lácteos de Asturias, Consejo Superior de Investigaciones Científicas, Paseo Río Linares s/n, 33300 Villaviciosa, Spain

e-mail:amargolles@ipla.csic.es
Probiotics are live microorganisms which when administered in adequate amounts confer a health benefit on the host. The main probiotic bacteria are strains belonging to the genera Lactobacillus and Bifidobacterium, although other representatives, such as Bacillus or Escherichia coli strains, have also been used. Lactobacillus and Bifidobacterium are two common inhabitants of the human intestinal microbiota. Also, some species are used in food fermentation processes as starters, or as adjunct cultures in the food industry. With some exceptions, antibiotic resistance in these beneficial microbes does not constitute a safety concern in itself, when mutations or intrinsic resistance mechanisms are responsible for the resistance phenotype. In fact, some probiotic strains with intrinsic antibiotic resistance could be useful for restoring the gut microbiota after antibiotic treatment. However, specific antibiotic resistance determinants carried on mobile genetic elements, such as tetracycline resistance genes, are often detected in the typical probiotic genera, and constitute a reservoir of resistance for potential food or gut pathogens, thus representing a serious safety issue.

Keywords: probiotics, Lactobacillus, Bifidobacterium, Bacillus, antibiotic resistance

\section{INTRODUCTION}

One of the most important selection criteria for bacterial strains intended for use in the food industry is concern for their safety. In Europe, according to the Qualified Presumption of Safety (QPS) approach, established by the European Food Safety Authority (EFSA, 2008), the nature of any antibiotic resistance determinant present in a candidate microorganism should be determined prior to approval for QPS status. Therefore, antibiotic resistance per se is not a safety issue; it only becomes such when the risk of resistance transfer is present.

Those probiotics belonging to species included in the EFSA QPS list (EFSA, 2012) have excellent safety records, and detrimental effects produced as a consequence of their ingestion are very scarce (Gouriet et al., 2012). Undoubtedly, a full safety assessment begins with a proper identification of the strain and an in vitro evaluation of the potential risks. In this regard, the presence of antibiotic resistance determinants, and their potential mobility, deserves special attention. Currently, it is generally accepted that the possibility of transfer is related to the genetic basis of the resistance mechanism, i.e., whether the resistance is intrinsic, acquired as a result of a chromosomal mutation(s), or acquired by horizontal gene transfer.

Most probiotics are common members of the human intestinal tract, and they are ingested in large amounts in functional foods, and the presence of antibiotic resistance determinants in their genome must be systematically screened. For instance, the bifidobacterial population in the human gut can be as high as $10^{11}$ cells/g of intestinal content, and even if the presence of the resistance genes are not a threat when they are present in bifidobacterial cells due to their lack of infectivity, these cells can constitute a reservoir from which genes could be transmitted to pathogenic bacteria. Thus, it is of great interest to investigate whether these determinants can be transferred in the food and gut environment
(Lahtinen et al., 2009). Furthermore, an important point to bear in mind is that animal probiotics are a source of live bacteria in the food chain, and in the European Union there has been an active policy to eliminate transmissible resistances in these products. Such concern must be also expressed regarding consumption of human probiotics.

In this review, we summarize the current knowledge on antibiotic resistance mechanisms in lactobacilli and bifidobacteria, as well as in other potential probiotic candidates, such as Bacillus strains. We did not consider enterococci because of the high prevalence of antibiotic resistance determinants in this genus and the obvious safety concerns.

\section{ANTIBIOTIC RESISTANCE DETERMINANTS IN Lactobacillus}

The genus Lactobacillus is the largest group among the lactic acid bacteria (LAB) and likely the most widely used as a probiotic in a variety of foods, mainly meat and fermented dairy products. To date, 182 species have been described within the genus (list of prokaryotic names with standing in nomenclature; www.bacterio.cict.fr/), giving an idea of its complexity. With regard to antibiotic resistance, the vancomycin-resistant phenotype of some lactobacilli is perhaps the best characterized intrinsic resistance in LAB. Vancomycin comes into contact with the peptidoglycan precursors on the cell wall side of the cytoplasmic membrane and binds to the D-alanine/D-alanine terminus of the pentapeptide, preventing polymerization of peptidoglycan precursors. In several species of $\mathrm{LAB}$, the terminal D-alanine residue is replaced by $\mathrm{D}$-lactate or $\mathrm{D}$-serine in the muramylpentapeptide, preventing vancomycin binding (Delcour et al., 1999) and therefore becoming resistant to the antibiotic. In addition, chromosomal mutations leading to antibiotic resistance phenotypes have also been described in lactobacilli. Flórez et al. (2007) identified a single mutation in the $23 \mathrm{~S}$ rRNA gene reducing the affinity 
of erythromycin for the ribosome. This mutation conferred macrolide resistance in a strain of L. rhamnosus. In this respect, the transfer risk is considered to be very low for intrinsic resistance, or acquired resistance due to chromosomal mutation(s). Nevertheless, knowledge of the antibiotic resistance phenotypes may still be important, even in the absence of transferable resistance; since lactobacilli are commonly used in food and feed products, intrinsic resistance might still be relevant for the treatment of Lactobacillus-related bacteremia (Cannon et al., 2005).

Horizontally transferred antibiotic resistance genes, particularly those carried within mobile genetic elements, are the most likely to be transmitted and thus deserve particular attention. A major step in the differentiation between the intrinsic and the acquired antibiotic resistance in probiotic bacteria is the determination and the comparison of antibiotic susceptibility patterns of a representative number of different strains from each species. Although some effort has been made to this end, work has only been carried out for some antibiotics and particular Lactobacillus species. These include the most commonly used probiotic species such as L. casei, L. acidophilus, L. reuteri, or L. rhamnosus, among others, or the yogurt starter bacteria L. delbrueckii (Ammor et al., 2008b; Korhonen et al., 2008; Mayrhofer et al., 2010). However, given the taxonomic complexity of this microbial genus, there is still a lack of agreement on the resistance susceptibility breakpoints for most antibiotics. The use of molecular methods, such as microarray analysis and various PCR techniques is being extremely helpful in determining the genetic basis of the acquired resistance phenotypes. Moreover, the increasing availability of genome sequences and the cost reduction of genome sequencing facilities offer new possibilities for the screening of antimicrobial resistance genes (Bennedsen et al., 2011).

With regard to specific antibiotics, lactobacilli are usually sensitive to the cell wall-targeting penicillin and $\beta$-lactamase, but are more resistant to cephalosporins. As previously mentioned, many Lactobacillus species show a high level of resistance to vancomycin. Also, most inhibitors of nucleic acid synthesis seem to have a low inhibitory effect among the majority of Lactobacillus species. On the other hand, lactobacilli are generally susceptible to low concentrations of many inhibitors of protein synthesis, such as chloramphenicol, macrolides, lincosamides, and tetracycline, but their resistance to aminoglycosides is often high. Resistance to other antibiotics varies greatly among lactobacilli.

Several genes responsible for atypical antibiotic resistance properties among lactobacilli have been reported (Table 1). Chloramphenicol resistance genes (cat; chloramphenicol acetyltransferases) have been identified in L. acidophilus, L. delbrueckii subsp. bulgaricus (Hummel et al., 2007), and L. johnsonii (Mayrhofer et al., 2010) as well as in L. reuteri (Lin et al., 1996) and L. plantarum (Ahn et al., 1992). In addition, erythromycin resistance genes, responsible for the macrolides, lincosamides, and streptogramins (MLS) resistance phenotype, have been identified in several Lactobacillus species; the erm(B) gene, which encodes a rRNA methylase acting on the $23 \mathrm{~S}$ ribosomal subunit, is the most frequently found of such genes, but others such as erm(A), erm(C), or erm(T) have also been detected (van Hoek et al., 2008c; Mayrhofer et al., 2010). The presence of genes coding for macrolide efflux pumps, such as mef(A), genes for lincosamide transferase
[lnu(A); Cauwerts et al., 2006] and streptogramin A acetyltransferases [vat(E); Gfeller et al., 2003; Mayrhofer et al., 2010] have also been reported. However, the most common resistance determinants found in lactobacilli are the tetracycline resistance genes, which are sometimes found in combination (Ammor et al., 2008c). At least 11 different tetracycline resistance genes have been detected to date in lactobacilli, these include genes coding for ribosomal protection proteins $[\operatorname{tet}(\mathrm{W}), \operatorname{tet}(\mathrm{M}), \operatorname{tet}(\mathrm{S}), \operatorname{tet}(\mathrm{O}), \operatorname{tet}(\mathrm{Q})$, tet $(36)$, tet $(\mathrm{Z}), \operatorname{tet}(\mathrm{O} / \mathrm{W} / 32 / \mathrm{O} / \mathrm{W} / \mathrm{O}), \operatorname{tet}(\mathrm{W} / \mathrm{O})]$ and efflux pumps $[\operatorname{tet}(\mathrm{K})$ and tet(L); Lahtinen et al., 2009]. Aminoglycoside resistance genes, such as $\operatorname{aac}\left(6^{\prime}\right)-\operatorname{aph}\left(2^{\prime \prime}\right)$, ant (6), and $a p h\left(3^{\prime}\right)$-IIIa (Rojo-Bezares et al., 2006), and $\beta$-lactam resistance genes (blaZ) were found much less frequently in lactobacilli (Aquilanti et al., 2007).

It is important to point out that many of the genetic determinants mentioned above are sometimes found in potentially mobile elements, such as transposons and plasmids, which could spread the antibiotic resistance genes mainly by conjugation mechanisms. The localization of these genes within the genome, their nucleotidic sequence, and the analysis of the flanking regions surrounding the antibiotic resistance genes may yield important clues as to the acquisition process of these determinants, and their source or origin (Aquilanti et al., 2007). Remarkably, some of these genes have been found to be transferred in vitro between strains of Lactobacillus and also from lactobacilli to different Gram-positive bacteria, including food pathogens, such as Staphylococcus (Tannock et al., 1994). On the other hand, lactobacilli may be able to acquire antibiotic determinants from other Gram-positive bacteria (Vescovo etal., 1983). In addition to in vitro studies, the potential risks associated with lactobacilli carrying transferable antibiotic resistance determinants have also been demonstrated in experimental animal models (Mater et al., 2008). The transfer of these determinants may be enhanced in the presence of antibiotic selective pressure (Feld et al., 2008). Taken together, these results support the hypothesis of the resistance gene reservoir within intestinal bacteria, and their role as traffickers in antibiotic resistance genes.

Another mechanism of resistance against antimicrobials known to be present in certain lactobacilli is that mediated by multidrug resistance (MDR) transporters. The role of drug resistance mediated by MDR systems in lactobacilli has been the subject of a previous review (Gueimonde et al., 2009). Although all lactobacilli have MDR homologs, information in this regard is limited, with only a few studies regarding the beer-spoiling L. brevis displaying resistance to hop compounds (Sakamoto et al., 2001), a proton motive force-dependent hop excretion transporter, named HorC, found in L. lindneri (Suzuki et al., 2005), or a MDR protein found to be involved in bile resistance in $L$. reuteri (Whitehead et al., 2008).

\section{ANTIBIOTIC RESISTANCE IN Bifidobacterium AND tet(W) UBIQUITY}

Bifidobacteria are members of the Actinobacteria phylum, one of the main phylogenetic groups of the human gut microbiota (Sánchez et al., 2013). Bifidobacterium infections are extremely rare and have involved immunocompromised patients in a few cases (Ohishi etal., 2010; Barberis etal., 2012; Jenke etal., 2012), but, to the best of our knowledge, the five species of 
Table 1 | Antibiotic resistance determinants identified and characterized in lactobacilli, bifidobacteria, and probiotic Bacillus strains.

\begin{tabular}{|c|c|c|c|c|}
\hline Gene(s) & Resistance & Mechanism & Location & Reference \\
\hline \multicolumn{5}{|l|}{ Lactobacillus } \\
\hline blaZ & $\beta$-Lactams & Antibiotic hydrolysis & - & Aquilanti et al. (2007) \\
\hline $\operatorname{vat}(\mathrm{E})$ & Quinupristin-dalfopristin & Antibiotic acetylation & - & Mayrhofer etal. (2010) \\
\hline Cat & Chloramphenicol & Antibiotic acetylation & Plasmid & $\begin{array}{l}\text { Ahn etal. (1992); Lin etal. (1996); } \\
\text { Hummel etal. (2007); Mayrhofer et al. (2010) }\end{array}$ \\
\hline msrC & MLS & Efflux & - & Thumu and Halami (2012) \\
\hline $\operatorname{mef}(\mathrm{A})$ & Macrolide & Efflux & - & Cauwerts etal. (2006) \\
\hline $\begin{array}{l}\operatorname{aac}\left(6^{\prime}\right)-\operatorname{aph}\left(2^{\prime \prime}\right), \operatorname{ant}(6), \\
\operatorname{aph}\left(3^{\prime}\right)-\text { IIla }\end{array}$ & Aminoglycoside & Enzymatic modification & - & Rojo-Bezares et al. (2006) \\
\hline $\begin{array}{l}\operatorname{erm}(B), \operatorname{erm}(C), \operatorname{erm}(T) \\
\operatorname{erm}(\mathrm{LF}), \operatorname{erm}(\mathrm{GT}), \operatorname{erm}(A)\end{array}$ & MLS & Ribosomal methylation & $\begin{array}{l}\text { Plasmid, transposon, } \\
\text { chromosome }\end{array}$ & $\begin{array}{l}\text { Tannock etal. (1994); Gfeller etal. (2003), } \\
\text { Cauwerts etal. (2006); Aquilanti etal. (2007), } \\
\text { Hummel etal. (2007); Klare etal. (2007), } \\
\text { Ammor etal. (2008b); Egervärn etal. (2009), } \\
\text { Mayrhofer etal. (2010); Thumu and Halami } \\
\text { (2012) }\end{array}$ \\
\hline $\begin{array}{l}\operatorname{tet}(\mathrm{W}), \operatorname{tet}(\mathrm{M}), \operatorname{tet}(\mathrm{S}), \\
\operatorname{tet}(\mathrm{O}), \operatorname{tet}(\mathrm{O}), \operatorname{tet}(36), \\
\operatorname{tet}(\mathrm{Z}), \operatorname{tet}(\mathrm{W} / \mathrm{O}), \\
\operatorname{tet}(\mathrm{O} / \mathrm{W} / 32 / \mathrm{O} / \mathrm{O})\end{array}$ & Tetracycline & Ribosomal protection & $\begin{array}{l}\text { Plasmid, transposon, } \\
\text { chromosome }\end{array}$ & $\begin{array}{l}\text { Aquilanti etal. (2007); Klare etal. (2007), } \\
\text { Ammor etal. (2008b), van Hoek etal. } \\
(2008 b, c)\end{array}$ \\
\hline tet $(\mathrm{K}) / \operatorname{tet}(\mathrm{L})$ & Tetracycline & Efflux & Plasmid & $\begin{array}{l}\text { Aquilanti etal. (2007); Ammor etal. (2008c), } \\
\text { Devirgiliis etal. (2009); Thumu and Halami } \\
\text { (2012) }\end{array}$ \\
\hline \multicolumn{5}{|l|}{ Bifidobacterium } \\
\hline $\operatorname{erm}(\mathrm{X})$ & MLS & Ribosomal methylation & Transposon & van Hoek et al. (2008a) \\
\hline $\begin{array}{l}\operatorname{tet}(\mathrm{W}), \operatorname{tet}(\mathrm{M}), \operatorname{tet}(\mathrm{O}) \\
\operatorname{tet}(\mathrm{W} / 32 / \mathrm{O}), \operatorname{tet}(\mathrm{O} / \mathrm{W})\end{array}$ & Tetracycline & Ribosomal protection & Chromosome & $\begin{array}{l}\text { Flórez et al. (2006); Kazimierczak etal. (2006), } \\
\text { Ammor etal. (2008a); van Hoek etal. (2008b) }\end{array}$ \\
\hline $\operatorname{tet}(\mathrm{L})$ & Tetracycline & Efflux & Chromosome & van Hoek et al. (2008b) \\
\hline \multicolumn{5}{|l|}{ Bacillus } \\
\hline$a a D 2$ & Aminoglycoside & Antibiotic adenylation & Chromosome & Bozdogan etal. (2003) \\
\hline erm(34) & MLS & Ribosomal protection & Chromosome & Bozdogan etal. (2004) \\
\hline$B C L-1$ & $\beta$-lactams & Antibiotic hydrolysis & Chromosome & Girlich et al. (2007) \\
\hline $\operatorname{cat}(\mathrm{Bcl})$ & Chloramphenicol & Antibiotic acetylation & Chromosome & Galopin et al. (2009) \\
\hline
\end{tabular}

Bifidobacterium with QPS status (B. adolescentis, B. animalis, B. bifidum, B. breve, and B. longum; EFSA, 2012) have not been linked to any infective processes in healthy individuals. However, several strains displaying antibiotic resistance phenotypes have been characterized, and in many cases the phenotype has been linked to specific antibiotic resistance genes, representing a potential risk of transfer to other bacteria in the intestinal ecosystem (Ammor et al., 2008b).

Bifidobacteria are intrinsically resistant to mupirocin, an antibiotic that is being used in selective media for this genus. Mupirocin competes with isoleucine as a substrate for isoleucyltRNA synthetase, thus affecting protein synthesis. The resistance phenotype of bifidobacteria is a consequence of the synthesis of an atypical isoleucyl-tRNA synthetase that contains key amino acid residues responsible for the high level of mupirocin resistance
(Serafini et al., 2011). Furthermore, they are not susceptible to high concentrations of aminoglycosides, most likely as a consequence of the lack of cytochrome-mediated drug transport (Mayrhofer etal., 2011). On the contrary, low concentrations of macrolides, vancomycin, chloramphenicol, beta-lactams, rifampicin, and spectinomycin, normally inhibit their growth (Zhou et al., 2005; Lahtinen et al., 2009). However, it is worth mentioning that a few streptomycin resistant strains have been characterized, leading to the conclusion that the resistance phenotype in these strains is due to chromosomal mutations, and not to the acquisition of specific antibiotic resistance genes, and therefore do not represent a potential risk of transferability. Thus, a high resistance to streptomycin was correlated with a mutation on the rpsL gene for ribosomal protein S12 in B. bifidum and B. breve (Kiwaki and Sato, 2009; Sato and Iino, 2010). Also, a 
B. bifidum strain displaying low erythromycin susceptibility was found to possess mutated $23 \mathrm{~S}$ ribosomal RNA gene copies, likely to be responsible for the observed phenotype (Sato and Iino, 2010).

Data on antibiotic resistance determinants in bifidobacteria are relatively scarce, and are limited to tetracycline and macrolide antibiotics (Table 1). MDR proteins have been described in $B$. longum and B. breve. The transporters are able to confer low resistance levels to erythromycin, although their contribution to the MLS phenotype remains to be determined (Margolles et al., 2005; Price et al., 2006). Also, a gene coding for a ribosomal protection protein, erm $(\mathrm{X})$, was identified in $B$. animalis subsp. lactis and $B$. thermophilum, as a part of the transposon Tn5432 (van Hoek et al., 2008a).

Tetracycline resistance in Bifidobacterium deserves special attention. We have known for more than a decade, that proteins that protect the ribosome from the action of tetracyclines, the so-called tet genes, are commonly found in this genus (Scott et al., 2000; Gueimonde et al., 2010). The genes tet(W), tet(M), tet $(\mathrm{O})$, tet $(\mathrm{W} / 32 / \mathrm{O})$, and tet $(\mathrm{O} / \mathrm{W})$ have been detected in several Bifidobacterium species, including B. longum (subsp. infantis and subsp. longum), B. breve, B. animalis subsp. lactis, B. bifidum, B. pseudocatenulatum, and B. thermophilum (Flórez et al., 2006; Kazimierczak etal., 2006; Aires et al., 2007, 2009; Ammor et al., 2008a; van Hoek et al., 2008b; Gueimonde et al., 2010). The gene tet (W) is especially ubiquitous; it has been detected at high frequencies in B. longum strains (Aires et al., 2007; Ammor et al., 2008a), and in all B. animalis subsp. lactis strains analyzed until now (Aires et al., 2007; Gueimonde et al., 2010). This last fact is very relevant, taking into account that $B$. animalis subsp. lactis strains are extensively used in the functional food industry, especially in fermented dairy products (Masco et al., 2005). The tet(W) gene in Bifidobacterium seems to be integrated in the chromosome and its surrounding regions vary depending on the strain, but very often the gene is flanked by transposase target sequences or genes coding for transposases, enzymes that catalyze the movement of DNA fragments between different locations by recognizing specific target sequences, suggesting that, under adequate conditions, the gene could be transferred (Kazimierczak et al., 2006; Ammor et al., 2008a; van Hoek et al., 2008a,b; Gueimonde et al., 2010). In fact, a tet $(\mathrm{W})$ gene of B. longum, containing a transposase located within the conserved upstream region of the gene, and flanked by imperfect direct repeats, was transferable, at low frequencies, between B. longum and B. adolescentis under in vitro conditions (Kazimierczak et al., 2006). This suggests the potential of bifidobacteria to transfer antibiotic resistance genes to closely related bacteria. However, although attempts have been made to demonstrate the donor capacity of bifidobacteria to other enteric bacteria, to the best of our knowledge this has not been experimentally proved yet.

\section{ANTIBIOTIC RESISTANCE GENES IN OTHER PROBIOTIC STRAINS}

Members of the genus Bacillus are aerobic or facultative aerobic, endospore-forming and rod-shaped Gram-positive bacteria, which inhabit a wide range of habitats, mostly soil and sediments. These bacteria do not belong to the commensal microbiota of the gastrointestinal tract, but some strains of the genus are included in food supplements and used in human nutrition as probiotics, notably Bacillus clausii (Ciffo, 1984). Furthermore, several Bacillus species have been employed for centuries in the manufacture of traditional, fermented dishes in Africa and Asia (Sarkar et al., 2002). Nowadays, certain Bacillus strains are used as feed additives, plant production products, biomass for animal feed, or enzyme/vitamin production (SCAN, 2000; Hong et al., 2005), and several species are included on the EFSA QPS list (EFSA, 2012). Many characteristics of probiotic Bacillus strains differ from those of other probiotic bacteria, including its ability to sporulate and the mechanisms of interaction with the human intestinal mucosa (Sánchez et al., 2009).

Regarding the presence of antibiotic-resistance mechanisms in Bacillus, macrolide-resistance genes present on extrachromosomal elements have been identified in mobile elements, such as the plasmid-encoded $\operatorname{erm}(\mathrm{C})$ from Bacillus subtilis (Monod et al., 1986). Tetracycline resistance determinants have also been found in mobile elements, including the plasmid-encoded tet $(\mathrm{L})$ gene from Bacillus subtilis (Phelan et al., 2011), and the tet(M) gene, contained within the conjugative transposon Tn5397 of Bacillus subtilis (Roberts et al., 1999). Other tetracycline resistance genes, such as tet $(\mathrm{K})$, have been observed in some Bacillus isolates (Neela etal., 2009). Recently, the presence of cfr-like genes in several Bacillus species has been reported. Cfr genes encode ribosome methyltransferases providing resistance to several classes of antibiotics including phenicols, oxazolidinone, lincosamides, pleuromutilins, and streptogramin A (Dai et al., 2010). However, these genes are not apparently expressed in the species assayed, in spite of being fully functional in other bacterial hosts (Hansen et al., 2012). In this regard, it is worth noting the presence of specific antibiotic resistance mechanisms in certain Bacillus clausii strains, which have been used as probiotics in humans, especially for the prevention of infectious bacterial diarrhea. For instance, the erm(34) gene has been identified in the probiotic Bacillus clausii DSM8716 strain (Bozdogan et al., 2004). Probiotic Bacillus clausii strains also harbor specific antibioticdefense mechanisms, such as an aminoglycoside resistance gene (aadD2), a chloramphenicol acetyltransferase gene, cat $(\mathrm{Bcl})$ or a $\beta$-lactamase (BCL-1; Bozdogan et al., 2003; Girlich et al., 2007; Galopin et al., 2009).

\section{CONCLUSION}

Bacteria naturally present in foods or food supplements, or deliberately added to them, including probiotic bacteria, constitute a potential source of antibiotic resistance determinants. Especially some fermented foods, such as dairy products, possess an extremely high bacterial density, mostly composed of LAB, quantitatively comparable with the microbial population found in some parts of the human intestine. This microbial population represents a huge reservoir of antibiotic resistance genes whose ingestion could influence the presence, establishment, and dynamics of antibiotic resistance bacteria in our body.

\section{ACKNOWLEDGMENTS}

We acknowledge the continuous support from the Plan Nacional de $I+D$ through several grants. Borja Sánchez was the recipient of a Juan de la Cierva postdoctoral contract from the Spanish Ministerio de Ciencia e Innovación. 


\section{REFERENCES}

Ahn, C., Collins-Thompson, D., Duncan, C., and Stiles, M. E. (1992). Mobilization and location of the genetic determinant of chloramphenicol resistance from Lactobacillus plantarum caTC2R. Plasmid 27, 169-176. doi: 10.1016/0147-619X (92)90018-6

Aires, J., Doucet-Populaire, F., and Butel, M. J. (2007). Tetracycline resistance mediated by tet( $\mathrm{W})$, tet( $\mathrm{M})$, and tet(O) genes of Bifidobacterium isolates from humans. Appl. Environ. Microbiol. 73, 2751-2754. doi: 10.1128/AEM.02459-06

Aires, J., Thouverez, M., DoucetPopulaire, F., and Butel, M. J. (2009). Consecutive human bifidobacteria isolates and acquired tet genes. Int. J. Antimicrob. Agents 33, 291-293. doi: 10.1016/j.ijantimicag.2008.09.013

Ammor, M. S., Flórez, A. B., AlvarezMartín, P., Margolles, A., and Mayo, B. (2008a). Analysis of tetracycline resistance tet $(\mathrm{W})$ genes and their flanking sequences in intestinal Bifidobacterium species. J. Antimicrob. Chemother. 62, 688-693. doi: 10.1093/jac/dkn280

Ammor, M. S., Flórez, A. B., Van Hoek, A. H. A. M., de los Reyes-Gavilán, C. G., Aarts, H. J. M., Margolles, A., et al. (2008b). Molecular characterization of intrinsic and acquired antibiotic resistance in lactic acid bacteria and bifidobacteria. J. Mol. Microbiol. Biotechnol. 14, 6-15.

Ammor, M. S., Gueimonde, M. Danielsen, M., Zagorec, M., van Hoek, A. H., de los Reyes-Gavilán, C. G., et al. (2008c). Two different tetracycline resistance mechanisms, plasmid-carried tet(L) and chromosomally located transposonassociated tet( $\mathrm{M})$, coexist in Lactobacillus sakei Rits 9. Appl. Environ. Microbiol. 74, 1394-1401. doi: 10.1128/AEM.01463-07

Aquilanti, L., Garofalo, C., Osimani, A., Silvestri, G., Vignaroli, C., and Clementi, F. (2007). Isolation and molecular characterization of antibiotic-resistant lactic acid bacteria from poultry and swine meat products. J. Food Prot. 70, 557-565.

Barberis, C. M., Cittadini, R. M., Almuzara, M. N., Feinsilberg, A., Famiglietti, A. M., Ramírez, M. S., et al. (2012). Recurrent urinary infection with Bifidobacterium scardovii. J. Clin. Microbiol. 50, 1086-1088. doi: 10.1128/JCM.06027-11

Bennedsen, M., Stuer-Lauridsen, B., Danielsen, M., and Johansen, E. (2011). Screening for antimicrobial resistance genes and virulence factors via genome sequencing. Appl. Environ. Microbiol. 77, 2785-2787. doi: 10.1128/AEM.02493-10

Bozdogan, B., Galopin, S., Gerbaud, G. Courvalin, P., and Leclercq, R. (2003). Chromosomal aadD2 encodes an aminoglycoside nucleotidyltransferase in Bacillus clausii. Antimicrob. Agents Chemother. 47, 1343-1346. doi: 10.1128/AAC.47.4. 1343-1346.2003

Bozdogan, B., Galopin, S., and Leclercq, R. (2004). Characterization of a new erm-related macrolide resistance gene present in probiotic strains of Bacillus clausii. Appl. Environ. Microbiol. 70, 280284. doi: 10.1128/AEM.70.1.280 284.2004

Cannon, J. P., Lee, T. A., Bolanos, J. T., and Danziger, L. H. (2005). Pathogenic relevance of Lactobacillus: a retrospective review of over 200 cases. Eur. J. Clin. Microbiol. Infect. Dis. 24, 31-40. doi: 10.1007/s10096004-1253-y

Cauwerts, K., Pasmans, F., Devriese, L. A., Martel, A., Haesebrouck, F., and Decostere, A. (2006). Cloacal Lactobacillus isolates from broilers show high prevalence of resistance towards macrolide and lincosamide antibiotics. Avian Pathol. 35, 160-164. doi: 10.1080/03079450600598137

Ciffo, F. (1984). Determination of the spectrum of antibiotic resistance of the "Bacillus subtilis" strains of Enterogermina. Chemioterapia 3 $45-52$.

Dai, L., Wu, C. M., Wang, M. G., Wang, Y., Wang, Y., Huang, S. Y., et al. (2010). First report of the multidrug resistance gene $\mathrm{cfr}$ and the phenicol resistance gene fexA in a Bacillus strain from swine feces. Antimicrob. Agents Chemother. 54, 3953-3955. doi: 10.1128/AAC. 00169-10

Delcour, J., Ferain, T., Deghorain, M. Palumbo, E., and Hols, P. (1999). The biosynthesis and functionality of the cell-wall of lactic acid bacteria. Antonie Van Leeuwenhoek 76, 159-184. doi: 10.1023/A:1002089 722581

Devirgiliis, C., Coppola, D., Barile, S., Colonna, B., and Perozzi, G. (2009). Characterization of the Tn916 conjugative transposon in a food-borne strain of Lactobacillus paracasei. Appl. Environ. Microbiol. 75, 3866-3871. doi: 10.1128/AEM. 00589-09

EFSA. (2008). Update of the criteria used in the assessment of bacterial resistance to antibiotics of human or veterinary importance. EFSA J. 732, 1-15.
EFSA. (2012). Scientific opinion on the maintenance of the list of QPS biological agents intentionally added to food and feed. EFSA J. 10, 3020. doi:10.2903/j.efsa.2011.2497

Egervärn, M., Roos, S., and Lindmark, H. (2009). Identification and characterization of antibiotic resistance genes in Lactobacillus reuteri and Lactobacillus plantarum. J. Appl. Microbiol. 107, 1658-1668. doi: 10.1111/j.1365-2672.2009.04352.x

Feld, L., Schjorring, S., Hammer, K., Licht, T. R., Danielsen, M., Krogfelt, K., et al. (2008). Selective pressure affects transfer and establishment of a Lactobacillus plantarum resistance plasmid in the gastrointestinal environment. J. Antimicrob. Chemother. 61, 845-852. doi: 10.1093/jac/dkn033

Flórez, A. B., Ammor, M. S., AlvarezMartín, P., Margolles, A., and Mayo, B. (2006). Molecular analysis of tet $(\mathrm{W})$ gene-mediated tetracycline resistance in dominant intestinal Bifidobacterium species from healthy humans. Appl. Environ. Microbiol. 72, 7377-7379.

Flórez, A. B., Ladero, V., Alvarez-Martín, P., Ammor, M. S., Alvarez, M. A., and Mayo, B. (2007). Acquired macrolide resistance in the human intestinal strain Lactobacillus rhamnosus E41 associated with a transition mutation in 23S rRNA genes. Int. J. Antimicrob Agents 30, 341-344.

Galopin, S., Cattoir, V., and Leclercq, R. (2009). A chromosomal chloramphenicol acetyltransferase determinant from a probiotic strain of Bacillus clausii. FEMS Microbiol. Lett. 296, 185-189. doi: 10.1111/j.15746968.2009.01633.x

Gfeller, K. Y., Roth, M., Meile, L. and Teuber, M. (2003). Sequence and genetic organization of the 19.3$\mathrm{kb}$ erythromycin- and dalfopristinresistance plasmid pLME300 from Lactobacillus fermentum ROT1. Plasmid 50, 190-201. doi: 10.1016/ j.plasmid.2003.08.001

Girlich, D., Leclercq, R., Naas, T., and Nordmann, P. (2007). Molecular and biochemical characterization of the chromosome-encoded class $\mathrm{A} \beta$-Lactamase BCL-1 from Bacillus clausii. Antimicrob. Agents Chemother. 51, 4009-4014. doi: 10.1128/AAC.00537-07

Gouriet, F., Million, M., Henri, M. Fournier, P. E., and Raoult, D. (2012). Lactobacillus rhamnosus bacteremia: an emerging clinical entity. Eur. J. Clin. Microbiol. Infect. Dis. 31, 24692480. doi: 10.1007/s10096-0121599-5

Gueimonde, M., Flórez, A. B., de los Reyes-Gavilán, C. G., and Margolles,
A. (2009). Intrinsic resistance in lactic acid bacteria and bifidobacteria: the role of multidrug resistance transporters. Int. J. Probiotics Prebiotics 4 181-186.

Gueimonde, M., Flórez, A. B., van Hoek, A. H., Stuer-Lauridsen, B., Strøman, P., de los Reyes-Gavilán, C. G., et al. (2010). Genetic basis of tetracycline resistance in Bifidobacterium animalis subsp. lactis. Appl. Environ. Microbiol. 76, 3364-3369.

Hansen, F., Sorensen, J., Giese, H., Sondergaard, T., and Frandsen, R. (2012). Quick guide to polyketide synthase and nonribosomal synthetase genes in Fusarium. Int. J. Food Microbiol. 155, 128-136. doi: 10.1016/j.ijfoodmicro.2012.01.018

Hong, H. A., le Duc, H., and Cutting, S. M. (2005). The use of bacterial spore formers as probiotics. FEMS Microbiol. Rev. 29, 813-835. doi: 10.1016/j.femsre.2004.12.001

Hummel, A. S., Hertel, C., Holzapfel, W. H., and Franz, C. M. (2007). Antibiotic resistances of starter and probiotic strains of lactic acid bacteria. Appl. Environ. Microbiol. 73, 730-739. doi: 10.1128/AEM. 02105-06

Jenke, A., Ruf, E. M., Hoppe, T., Heldmann, M., and Wirth, S. (2012). Bifidobacterium septicaemia in an extremely low-birthweight infant under probiotic therapy. Arch. Dis. Child Fetal Neonatal Ed. 97, F217F218. doi: 10.1136/archdischild2011-300838

Kazimierczak, K. A., Flint, H. J., and Scott, K. P. (2006). Comparative analysis of sequences flanking tet $(\mathrm{W})$ resistance genes in multiple species of gut bacteria. Antimicrob. Agents Chemother. 50, 2632-2639. doi: 10.1128/AAC.01587-05

Kiwaki, M., and Sato, T. (2009). Antimicrobial susceptibility of Bifidobacterium breve strains and genetic analysis of streptomycin resistance of probiotic B. breve strain Yakult. Int. J. Food Microbiol. 134, 211215. doi: 10.1016/j.ijfoodmicro.2009. 06.011

Klare, I., Konstabel, C., Werner, G., Huys, G., Vankerckhoven, V., Kahlmeter, G., et al. (2007). Antimicrobial susceptibilities of Lactobacillus, Pediococcus and Lactococcus human isolates and cultures intended for probiotic or nutritional use. J. Antimicrob. Chemother. 59, 900-912. doi: 10.1093/jac/ dkm035

Korhonen, J. M., Danielsen, M., Mayo, B., Egervarn, H., Axelsson, L., Huys, G., et al. (2008). Antimicrobial susceptibility and proposed 
microbiological cut-off values of lactobacilli by phenotypic determination. Int. J. Probiotics Prebiotics 3, 257-268.

Lahtinen, S. J., Boyle, R. J., Margolles, A., Frías, R., and Gueimonde, M. (2009). "Safety assessment of probiotics," in Prebiotics and Probiotics Science and Technology, eds D. Charalampopoulos and R. A. Rastall (Berlin: SpringerVerlag), 1193-1225.

Lin, C. F., Fung, Z. F., Wu, C. L., and Chung, T. C. (1996). Molecular characterization of a plasmid-borne (pTC82) chloramphenicol resistance determinant (cat-TC) from Lactobacillus reuteri G4. Plasmid 36, 116 124. doi: 10.1006/plas.1996.0039

Margolles, A., Moreno, J. A., van Sinderen, D., and de los ReyesGavilán, C. G. (2005). Macrolide resistance mediated by a Bifidobacterium breve membrane protein. Antimicrob. Agents Chemother. 49, 4379-4381. doi: 10.1128/AAC.49.10. 4379-4381.2005

Masco, L., Huys, G., De Brandt, E., Temmerman, R., and Swings, J. (2005). Culture-dependent and culture-independent qualitative analysis of probiotic products claimed to contain bifidobacteria. Int. J. Food Microbiol. 102, 221-230. doi: 10.1016/j.ijfoodmicro.2004.11.018

Mater, D. D., Langella, P., Corthier, G., and Flores, M. J. (2008). A probiotic Lactobacillus strain can acquire vancomycin resistance during digestive transit in mice. J. Mol. Microbiol. Biotechnol. 14, 123-127. doi: 10.1159/000106091

Mayrhofer, S., Mair, C., Kneifel, W., and Domig, K. J. (2011). Susceptibility of bifidobacteria of animal origin to selected antimicrobial agents. Chemother. Res. Pract. 989520. doi: 10.1155/2011/989520

Mayrhofer, S., van Hoeck, A. H. A. M., Mair, C., Huys, G., Arts, H. J. M., Kneifel, W., et al. (2010). Antibiotic susceptibility of members of the Lactobacillus acidophilus group using broth microdilution and molecular identification of their resistance determinants. Int. J. Food Microbiol. 144, 8187. doi: 10.1016/j.ijfoodmicro.2010. 08.024

Monod, M., Denoya, C., and Dubnau, D. (1986). Sequence and properties of pIM13, a macrolide-lincosamidestreptogramin B resistance plasmid from Bacillus subtilis. J. Bacteriol. 167, 138-147.

Neela, F. A., Nonaka, L., Rahman, M. H., and Suzuki, S. (2009). Transfer of the chromosomally encoded tetracycline resistance gene tet(M) from marine bacteria to Escherichia coli and Enterococcus faecalis. World J. Microbiol. Biotechnol. 25, 1095-1101. doi: 10.1007/s11274-009-0004-8

Ohishi, A., Takahashi, S., Ito, Y., Ohishi, Y., Tsukamoto, K., Nanba, Y., et al. (2010). Bifidobacterium septicemia associated with postoperative probiotic therapy in a neonate with omphalocele. J. Pediatr. 156, 679681. doi: 10.1016/j.jpeds.2009.11.041 Phelan, R. W., Clarke, C., Morrissey, J. P., Dobson, A. D., O'Gara, F., and Barbosa, T. M. (2011). Tetracycline resistance-encoding plasmid from Bacillus sp. strain \#24, isolated from the marine sponge Haliclona simulans. Appl. Environ. Microbiol. 77, 327-329. doi: 10.1128/AEM. 01239-10

Price, C. E., Reid, S. J., Driessen, A. J., and Abratt, V. R. (2006). The Bifidobacterium longum NCIMB 702259Tctr gene codes for a novel cholate transporter. Appl. Environ. Microbiol. 72, 923-926. doi: 10.1128/AEM.72.1.923-926.2006

Roberts, A. P., Pratten, J., Wilson, M. and Mullany, P. (1999). Transfer of a conjugative transposon, Tn5397 in a model oral biofilm. FEMS Microbiol. Lett. 177, 63-66. doi: 10.1111/j.15746968.1999.tb13714.x

Rojo-Bezares, B., Sáenz, Y., Poeta, P., Zarazaga, M., Ruiz-Larrea, F., and Torres, C. (2006). Assessment of antibiotic susceptibility within lactic acid bacteria strains isolated from wine. Int. J. Food Microbiol. 111, 234-240.

Sakamoto, K., Margolles, A., van Veen, H. W., and Konings, W. N. (2001). Hop resistance in the beer spoilage bacterium Lactobacillus brevis is mediated by the ATP-binding cassette multidrug transporter HorA. J. Bacteriol. 183, 5371-5375. doi: 10.1128/JB.183.18.5371-5375.2001

Sánchez, B., Arias, S., Chaignepain, S., Denayrolles, M., Schmitter, J. M., Bressollier, P., et al. (2009). Identification of surface proteins involved in the adhesion of a probiotic Bacillus cereus strain to mucin and fibronectin. Microbiology 155, 1708-1716. doi: 10.1099/mic.0. 025288-0

Sánchez, B., Ruiz, L., Gueimonde, M., Ruas-Madiedo, P., and Margolles, A. (2013). Adaptation of bifidobacteria to the gastrointestinal tract and functional consequences. Pharmacol. Res. 69, 127-136. doi: 10.1016/j.phrs.2012.11.004

Sarkar, P. K., Hasenack, B., and Nout, M. J. (2002). Diversity and functionality of Bacillus and related genera isolated from spontaneously fermented soybeans (Indian Kinema) and locust beans (African Soumbala). Int. J. Food Microbiol. 77, 175-186. doi: 10.1016/S0168-1605(02)00124-1

Sato, T., and Iino, T. (2010). Genetic analyses of the antibiotic resistance of Bifidobacterium bifidum strain Yakult YIT 4007. Int. J. Food Microbiol. 137, 254-258. doi: 10.1016/j.ijfoodmicro.2009.12.014

SCAN (Scientific Committee on Animal Nutrition, European Commission). (2000). Opinion on the Safety of Use of Bacillus Species in Animal Nutrition. Available at: http://ec.europa.eu/food/fs/sc/scan/ out41_en.pdf.

Scott, K. P., Melville, C. M., Barbosa, T. M., and Flint, H. J. (2000). Occurrence of the new tetracycline resistance gene tet $(\mathrm{W})$ in bacteria from the human gut. Antimicrob. Agents Chemother. 44, 775-777. doi: 10.1128/AAC.44.3.775-777.2000

Serafini, F., Bottacini, F., Viappiani, A., Baruffini, E., Turroni, F., Foroni, E., et al. (2011). Insights into physiological and genetic mupirocin susceptibility in bifidobacteria. Appl. Environ. Microbiol. 77, 3141-3146. doi: 10.1128/AEM.02540-10

Suzuki, K., Iijima, K., Ozaki, K., and Yamashita, H. (2005). Isolation of a hop-sensitive variant of Lactobacillus lindneri and identification of genetic markers for beer spoilage ability of lactic acid bacteria. Appl. Env iron. Microbiol. 71, 5089-5097. doi: 10.1128/AEM.71.9.5089-5097.2005

Tannock, G. W., Luchansky, J. B., Miller, L., Connell, H., Thode-Andersen, S., Mercer, A. A., et al. (1994). Molecular characterization of a plasmid-borne (pGT633) erythromycin resistance determinant (ermGT) from Lactobacillus reuteri 100-63. Plasmid 31, 60-71. doi: 10.1006/plas.1994.1007

Thumu, S. C., and Halami, P. M. (2012). Presence of erythromycin and tetracycline resistance genes in lactic acid bacteria from fermented foods of Indian origin. Antonie Van Leeuwenhoek 102, 541-551. doi: 10.1007/s10482-012-9749-4

van Hoek, A. H., Mayrhofer, S., Domig, K. J., and Aarts, H. J. (2008a). Resistance determinant erm $(\mathrm{X})$ is borne by transposon Tn5432 in Bifidobacterium thermophilum and Bifidobac terium animalis subsp. lactis. Int. J. Antimicrob. Agents. 31, 544-548. doi: 10.1016/j.ijantimicag.2008.01.025

van Hoek, A. H., Mayrhofer, S., Domig, K. J., Flórez, A. B., Ammor, M. S., Mayo, B., et al. (2008b)
Mosaic tetracycline resistance genes and their flanking regions in Bifidobacterium thermophilum and Lactobacillus johnsonii. Antimicrob. Agents Chemother. 52, 248-252.

van Hoek, A. H. A. M., Margolles, A., Damig, K. J., Korhonen, J. M., ZyckaKrzesinka, J., Bardowsky, J., et al. (2008c). Molecular assessment of erythromycin and tetracycline resistance genes in lactic acid bacteria and bifidobacteria and their relation to the phenotypic resistance. Int. J. Probiotics Prebiotics 3, 271-280.

Vescovo, M., Morelli, L., Bottazzi, V., and Gasson, M. J. (1983). Conjugal transfer of broad-host-range plasmid pAMbetal into enteric species of lactic acid bacteria. Appl. Environ. Microbiol. 46, 753-755.

Whitehead, K., Versalovic, J., Roos, S., and Britton, R. A. (2008). Genomic and genetic characterization of the bile stress response of probiotic Lactobacillus reuteri ATCC 55730. Appl. Environ. Microbiol. 74, 1812-1819. doi: 10.1128/AEM. 02259-07

Zhou, J. S., Pillidge, C. J., Gopal, P. K., and Gill, H. S. (2005). Antibiotic susceptibility profiles of new probiotic Lactobacillus and Bifidobacterium strains. Int. J. Food Microbiol. 98, 211-217. doi: 10.1016/ j.ijfoodmicro.2004.05.011

Conflict of Interest Statement: The authors declare that the research was conducted in the absence of any commercial or financial relationships that could be construed as a potential conflict of interest.

Received: 28 March 2013; paper pending published: 17 April 2013; accepted: 28 June 2013; published online: 18 July 2013.

Citation: Gueimonde $M$, Sánchez B, de los Reyes-Gavilán CG and Margolles A (2013) Antibiotic resistance in probiotic bacteria. Front. Microbiol. 4:202. doi: 10.3389/fmicb.2013.00202

This article was submitted to Frontiers in Antimicrobials, Resistance and Chemotherapy, a specialty of Frontiers in Microbiology.

Copyright (C) 2013 Gueimonde, Sánchez, de los Reyes-Gavilán and Margolles. This is an open-access article distributed under the terms of the Creative Commons Attribution License, which permits use, distribution and reproduction in other forums, provided the original authors and source are credited and subject to any copyright notices concerning any thirdparty graphics etc. 